\title{
A bile acid derived potassium ion sensor
}

\author{
Uday Maitra* and Suvadeep Nath \\ Department of Organic Chemistry, Indian Institute of Science, \\ Bangalore 560 012, India \\ * Also at the Chemical Biology Unit, JNCASR, Bangalore 560 064, India \\ E-mail: maitra@orgchem.iisc.ernet.in
}

\section{Dedicated to Dr. A. V. Rama Rao on the occasion of his $70^{\text {th }}$ birthday}

(received 15 Oct 04; accepted 14 Dec 04; published on the web 15 Dec 04)

\begin{abstract}
A chenodeoxycholic acid based $\mathrm{K}^{+}$ion sensor has been designed using a modular approach in which a fluorophore and a cation receptor are attached to the bile acid backbone. In the absence of $\mathrm{K}^{+}$the fluorescence of the molecule is quenched because of through-space, photo-induced electron-transfer from the aza-crown unit. Fluorescence enhancement was observed upon titration with $\mathrm{K}^{+}$(and other alkali metal ions too). In methanol, good selectivity towards the sensing of $\mathrm{K}^{+}$has been observed.
\end{abstract}

Keywords: Photo-induced electron transfer (PET), fluorescence enhancement, aza-crown, bile acid, cation-sensor

\section{Introduction}

The design of ion sensors based on photo-induced electron-transfer (PET) mechanism are attracting interest in recent years for their applications in fields like analytical, medical science, and molecular electronics. ${ }^{1}$ Such a sensor molecule combines a fluorophore and a receptor module, and the sensing of metal ion relies typically on the enhancement of fluorescence when the cation binds to the receptor module. In an azacrown ether - spacer - fluorophore system, the nitrogen lone pair quenches the fluorescence of the fluorophore. When a metal ion binds, the nitrogen lone pair is engaged through coordination to the cation causing fluorescence enhancement. The efficiency of PET process depends on the distance between the quencher moiety and the fluorophore. The effect of spacer length on the emission properties of a pyrene fluorophore upon alkali metal ion complexation by 1-aza-18-crown-6 has been studied extensively, which showed that the efficiency of the PET process was higher for shorter spacers. ${ }^{2}$ 
Bile acids contain a varying number of $\mathrm{OH}$ groups on the $\alpha$-face of the molecule positioned at distances appropriate for the design of a cation sensor. ${ }^{3}$ We have designed a bile acid based sensor molecule 3 in which the pyrene fluorophore and the aza-18-crown-6 receptor are linked formally via a 1, 5-diol. The rigidity of the steroid backbone allows the fluorophore and the receptor module to be in close proximity.

\section{Results and Discussion}

Methyl chenodeoxycholate was selectively acylated with pyrene-1-carboxylic acid at the $3 \alpha$ position to yield 1 (43\%), which was converted to its chloroacetyl derivative 2 (65\%), and finally reacted with 1-aza-18-crown-6 to form the desired product 3 in 55\% yield (Scheme 1).

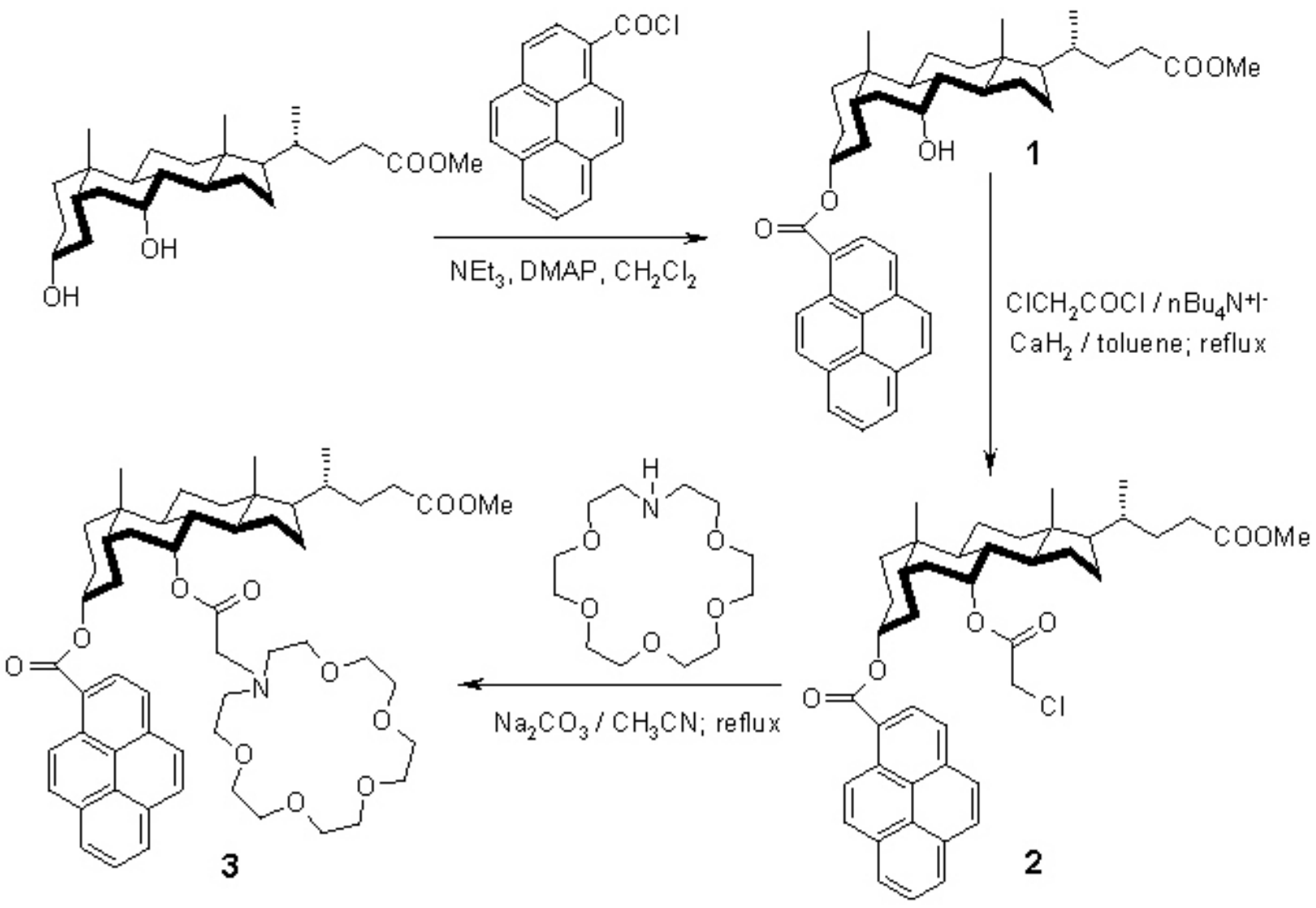

\section{Scheme 1}

Binding constants for the association of different alkali metal cations and $\mathrm{NH}_{4}{ }^{+}$with 3 in $\mathrm{CHCl}_{3}$ at $20{ }^{\circ} \mathrm{C}$ were determined by Cram's picrate extraction method, ${ }^{5}$ and the estimated 
binding constants are, $\log \mathrm{K}_{\mathrm{a}}\left(\mathrm{K}^{+}\right)$7.47; $\log \mathrm{K}_{\mathrm{a}}\left(\mathrm{NH}_{4}{ }^{+}\right)$6.75; $\log \mathrm{K}_{\mathrm{a}}\left(\mathrm{Na}^{+}\right)$6.11; $\log \mathrm{K}_{\mathrm{a}}\left(\mathrm{Li}^{+}\right)$4.49. This order is in accordance with published data. ${ }^{6}$

Fluorescence titration experiments were subsequently carried out using $5 \mu \mathrm{M}$ of $\mathbf{3}$ in $4: 1$ toluene/acetonitrile. $\mathrm{KClO}_{4}, \mathrm{NH}_{4} \mathrm{PF}_{6}, \mathrm{NaBF}_{4}$, and $\mathrm{LiClO}_{4}$ were used as analytes in varying concentrations. In all the cases the fluorescence intensity increased with the guest concentrations and reached a saturation value at $\sim 5 \mu \mathrm{M}$ suggesting 1:1 complexation (Figure 1).

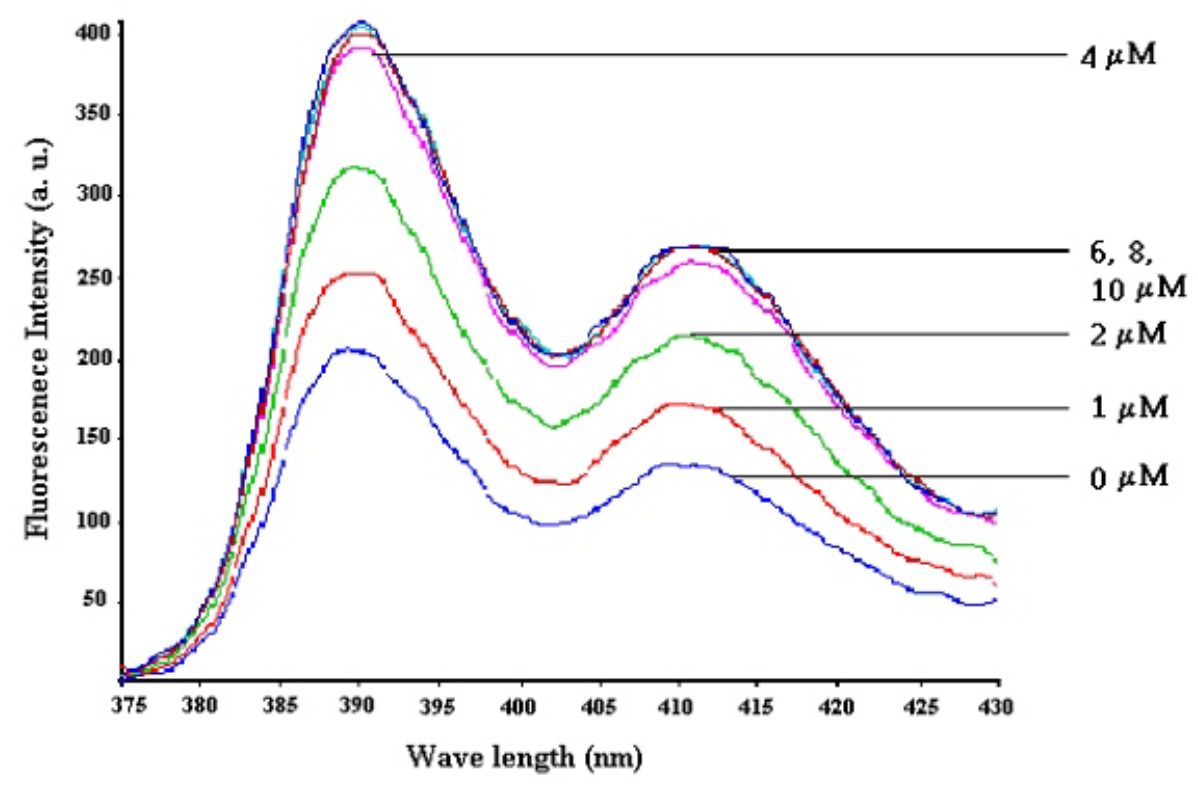

Figure 1. Fluorescence titration of $5 \mu \mathrm{M}$ soln. of $\mathbf{3}(4: 1 \mathrm{PhMe} / \mathrm{MeCN})$ with $\mathrm{KClO}_{4}$.

The increase in the fluorescence intensity differed slightly with the cation. There was a small difference in the initial slopes of the curves when the fluorescence enhancement was plotted against the salt concentration. There was a gradual decrease in the slopes as the following order $\mathrm{K}^{+} \sim \mathrm{NH}_{4}{ }^{+}>\mathrm{Na}^{+}>\mathrm{Li}^{+}$(Figure 2). 


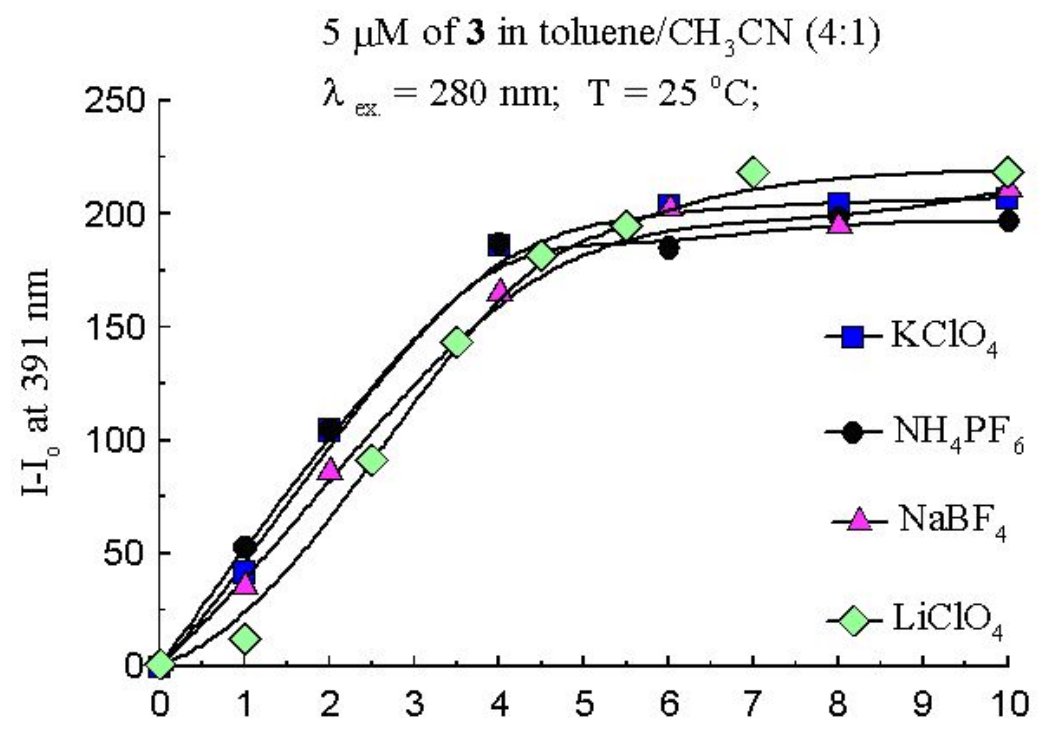

Figure 2. Increase in fluorescence intensity of $\mathbf{3}$ in 4:1 toluene/acetonitrile with added salt, showing 1:1 complexation $I, I_{o}$ are fluorescence intensities in the presence and absence of salt.

To explore the difference in the fluorescence enhancement for different guests, the same experiment was performed at a lower sensor concentration $(0.2 \mu \mathrm{M})$. As expected, different slopes for the increment of the fluorescence intensity with the concentration of the cations was observed with $\mathrm{K}^{+}$showing a higher slope compared to $\mathrm{Li}^{+}$because of its higher binding affinity (Figure 3).

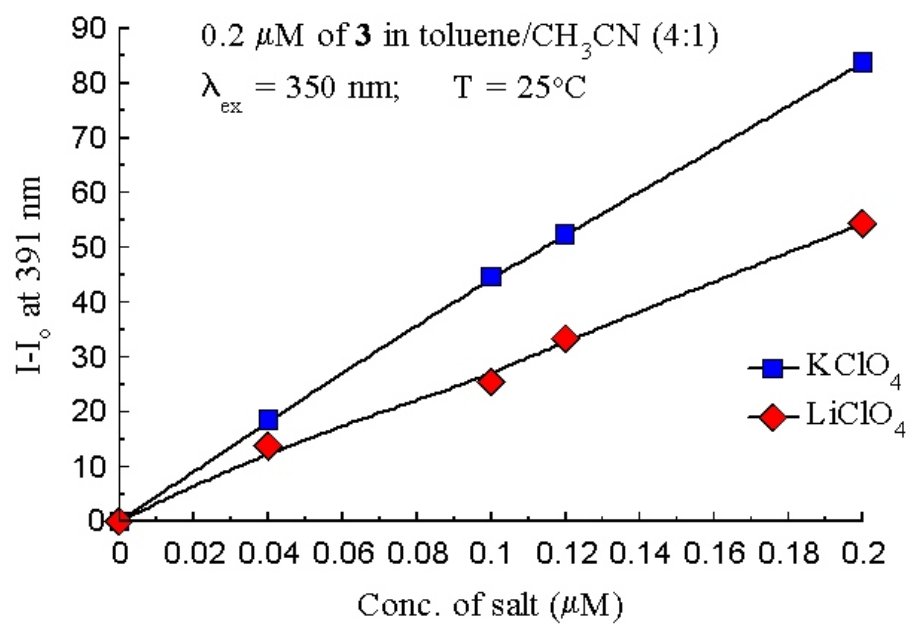

Figure 3. Increase in fluorescence intensity of 3 with added salt in $4: 1 \mathrm{PhMe} / \mathrm{MeCN}$.

Since the difference in the slopes in 4:1 toluene/ acetonitrile for different cations was not significantly different, the same experiment was performed in $\mathrm{MeOH}$ to enhance the selectivity. 
When a $1 \mu \mathrm{M}$ solution of 3 in $\mathrm{MeOH}$ was titrated with cations a sharp increase in the fluorescence intensity was observed with $\mathrm{K}^{+}$, while $\mathrm{Na}^{+}$showed significantly less enhancement and $\mathrm{Li}^{+}$didn't show any enhancement upto $10 \mu \mathrm{M}$ of $\mathrm{LiClO}_{4}$ (Fig. 4).

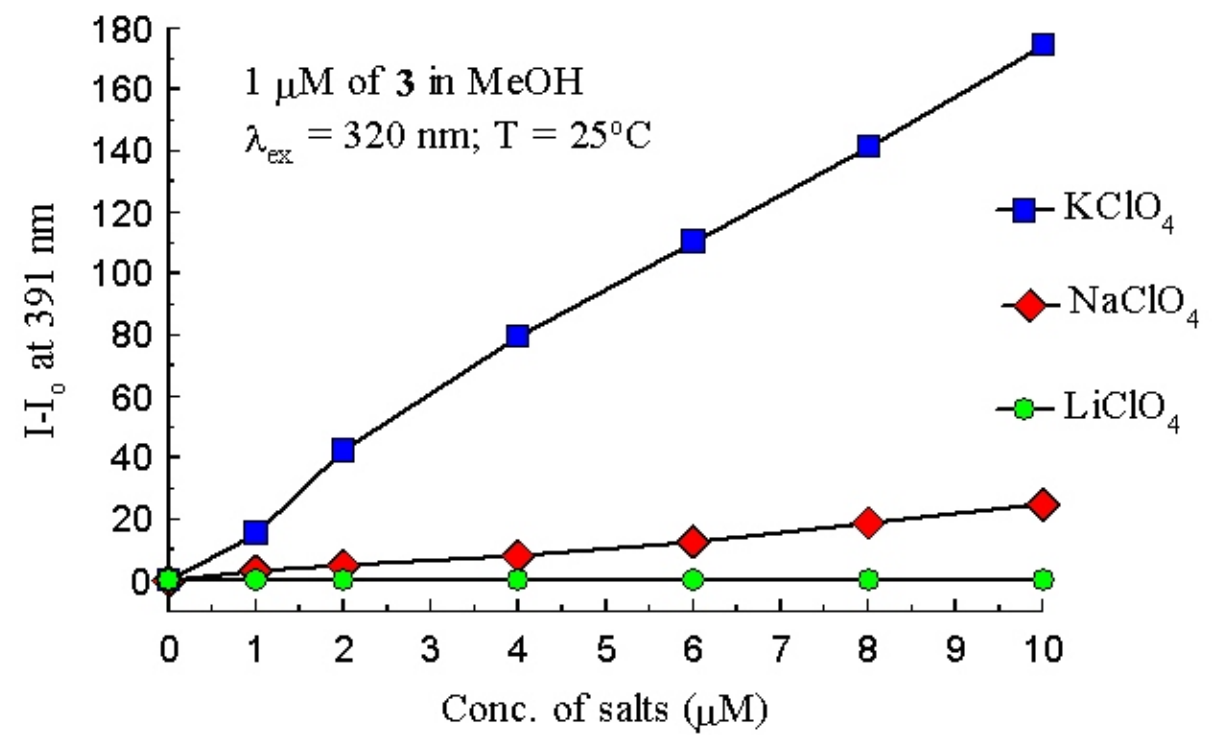

Figure 4. Increase in fluorescence intensity of $\mathbf{3}$ with various guests in $\mathrm{MeOH}$, and the sensitivity is high when the guest is $\mathrm{K}^{+}$.

To verify the fluorescence enhancement behavior for a mixture of $\mathrm{K}^{+}$and $\mathrm{Na}^{+}$ions, competition experiments were done by varying the concentrations of $\mathrm{Na}^{+}$and $\mathrm{K}^{+}$in $\mathrm{MeOH}$. At low $\left[\mathrm{K}^{+}\right]$a small fluorescence enhancement due to the addition of $\mathrm{Na}^{+}$could be observed. On the other hand, at higher potassium concentration the effect of sodium was insignificant because of the saturation of the binding sites (Figure 5). When the fluorescence enhancement was plotted against $\left[\mathrm{K}^{+}\right]$at different constant $\left[\mathrm{Na}^{+}\right]$, a lowering of the slope was observed at higher $\left[\mathrm{Na}^{+}\right]$ which indicated that the influence of added $\mathrm{Na}^{+}$was predominant only at low $\mathrm{K}^{+}$concentration (Figure 6). The data from Fig. 5 and 6 are presented in a 3D format in Figure 7. It is noteworthy that $1 \mu \mathrm{M}$ of $\mathrm{K}^{+}$could be sensed in the presence of $40 \mu \mathrm{M}$ of $\mathrm{Na}^{+}$. 


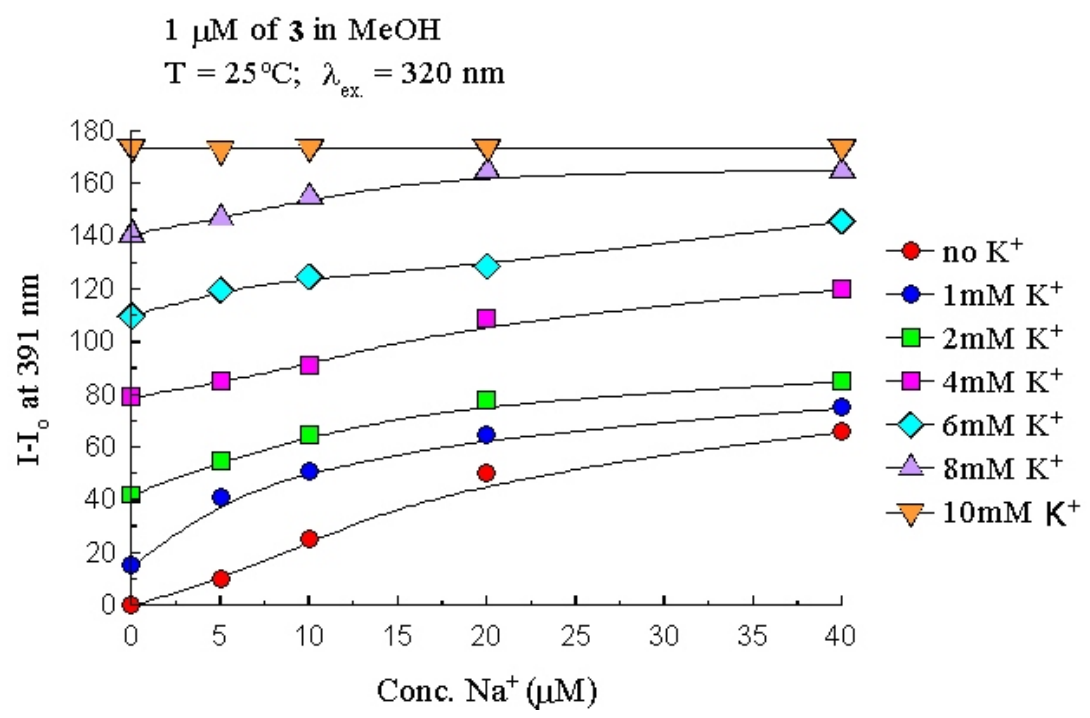

Figure 5. Change in the fluorescence intensities of 3 with $\mathrm{Na}^{+}$keeping $\mathrm{K}^{+}$concentration constant in $\mathrm{MeOH}$.

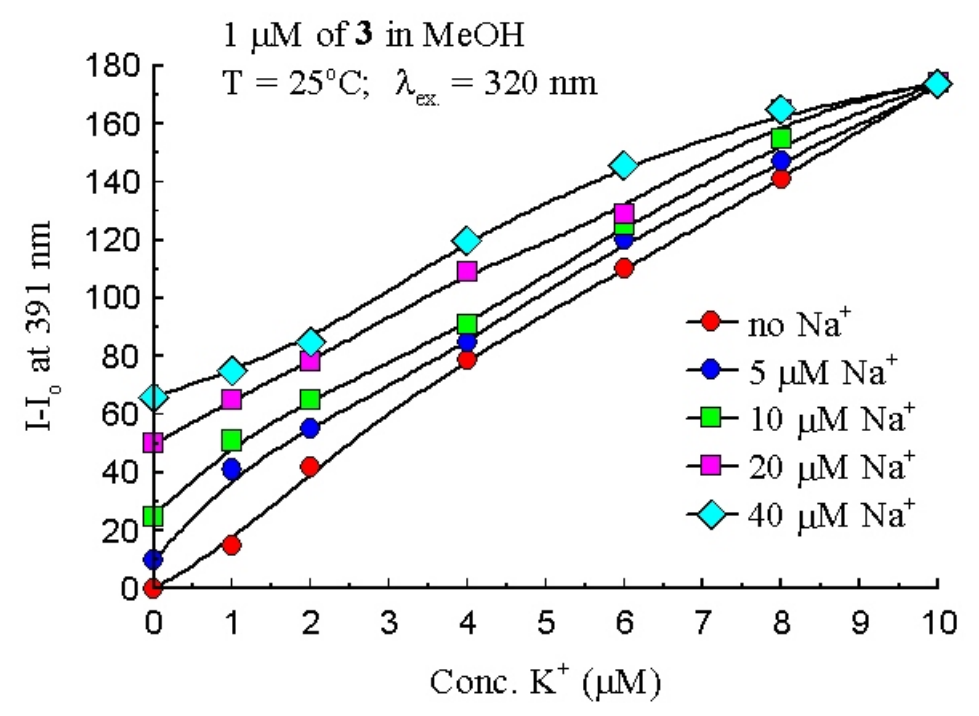

Figure 6. Change in the fluorescence intensities of $\mathbf{3}$ with $\mathrm{K}^{+}$keeping $\mathrm{Na}^{+}$concentration constant in $\mathrm{MeOH}$. 


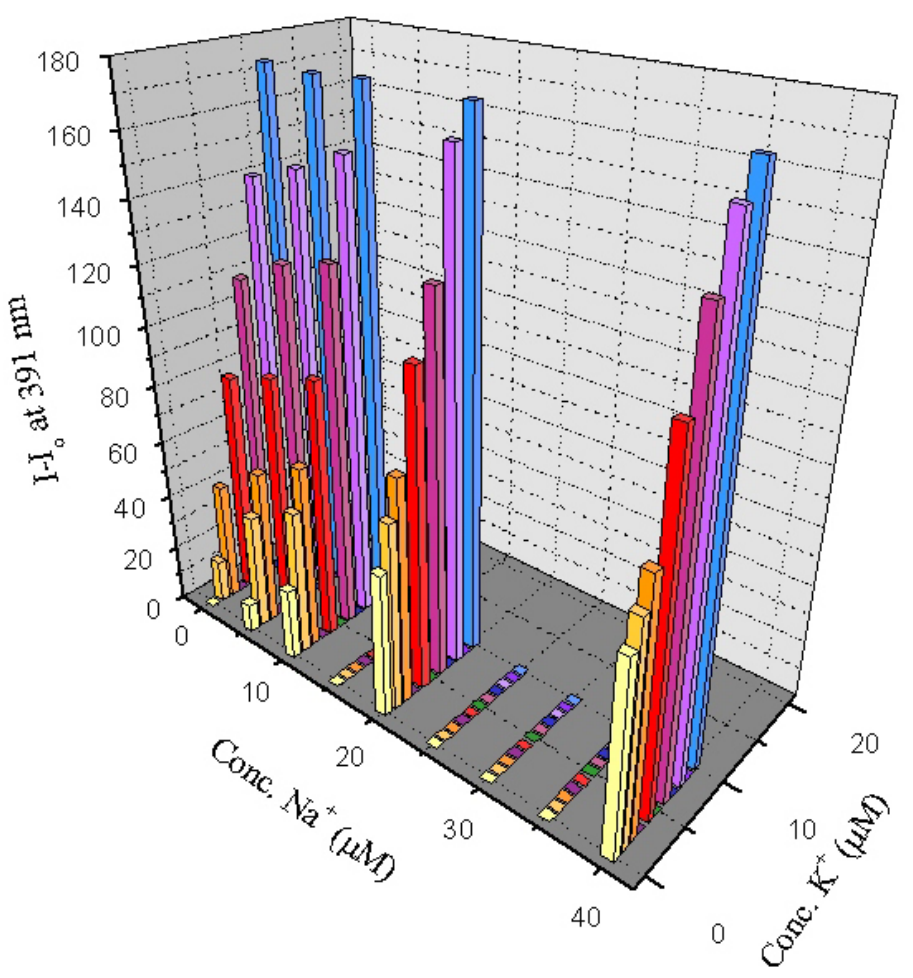

Figure 7. Relative fluorescence enhancement of $\mathbf{3}$ in $\mathrm{MeOH}$ for mixtures of $\mathrm{K}^{+}$and $\mathrm{Na}^{+}$.

The increase in the fluorescence intensity upon cation binding can be explained on the basis of a PET mechanism (Figure 8).

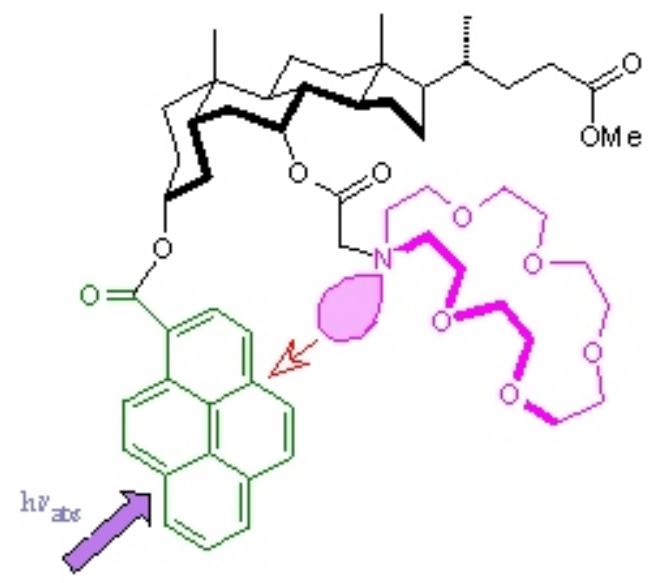

Less Fluorescent ("OFF" State)

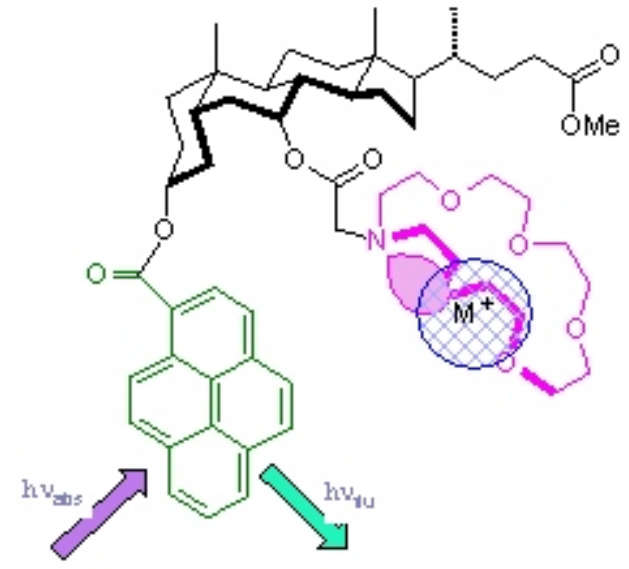

Highly Fluorescent ("ON" State)

Figure 8. Quenching of fluorescence due to PET and enhancement of pyrene fluorescence upon binding to cations. 
To confirm the phenomena as a through-space PET process, analog $\mathbf{4}^{3}$ (Figure 9) was tested under identical conditions. A methanolic solution of 4 at $1 \mu \mathrm{M}$ showed a higher fluorescence intensity compared to 3 at the same conc. and didn't increase much upon the addition of $\mathrm{KClO}_{4}$ (Figure 10) or $\mathrm{NaClO}_{4}$. Unlike 3, the distance between the two modules is larger in 4, and thus the pyrene fluorescence was not quenched. Another control experiment with non-covalently linked fluorophore and the aza-crown receptor (each at $1 \mu \mathrm{M}$ ) showed no change in the fluorescence intensity in the presence of alkali metal ions, suggesting that an appropriate geometry and distance is a prerequisite for the 'through space photo induced electron transfer' process.

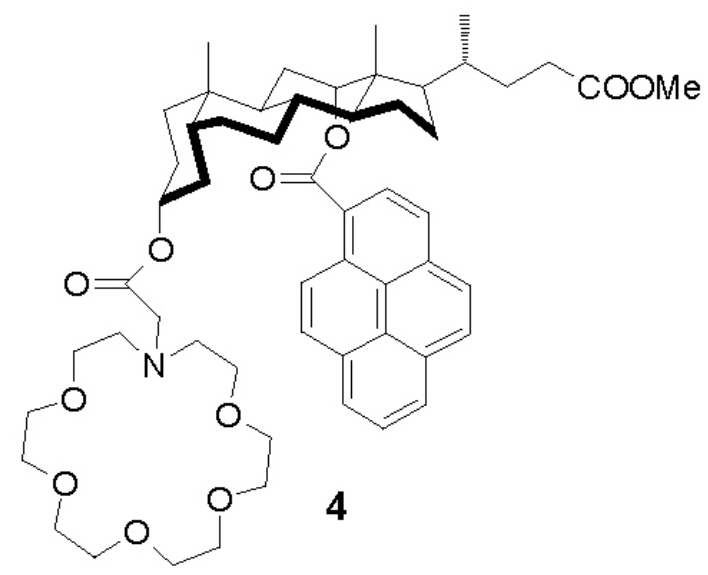

Figure 9. Structural analog of $\mathbf{3}$.

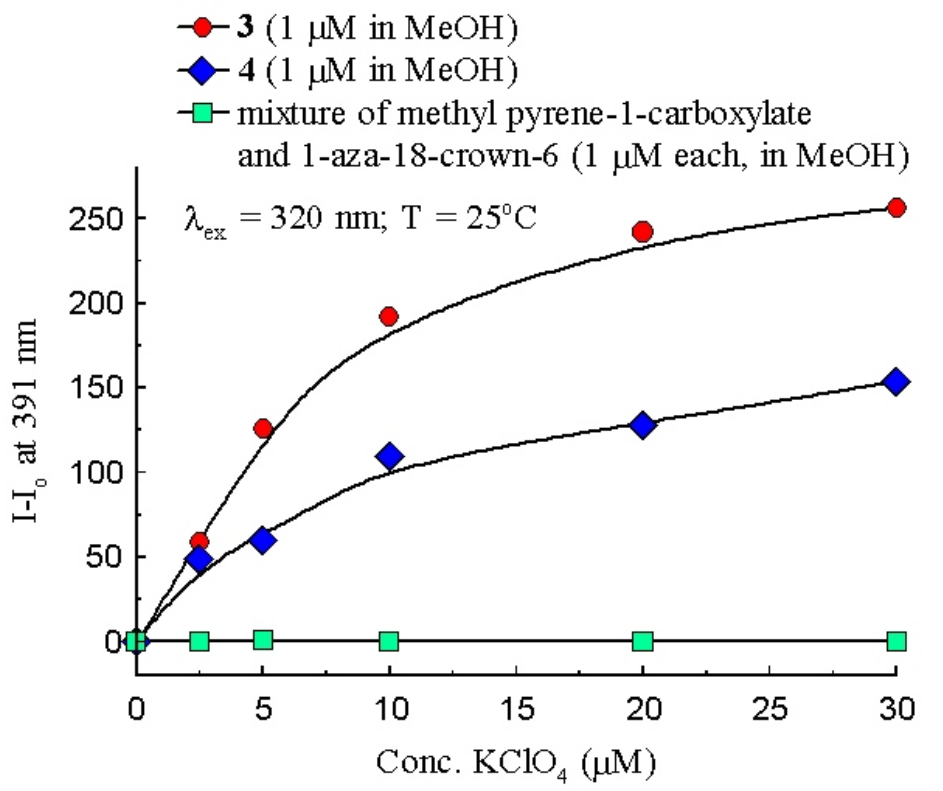

Figure 10. The fluorescence enhancement with $\left[\mathrm{K}^{+}\right]$for $\mathbf{3}$ is higher as compared to that of $\mathbf{4}$, while a 1:1 mixture of methyl pyrene-1-carboxylate and 1-aza-18-crown-6 does not show any enhancement with $\mathrm{K}^{+}$. 


\section{Conclusions}

In conclusion, we have synthesized a bile acid based PET sensor for alkali metal ions, where PET occurs through space and the fluorescence quenching process is inhibited upon binding to alkali metal ions. Using this sensor, $<0.2 \mu \mathrm{M}$ of $\mathrm{K}^{+}$can be determined in 4:1 toluene/acetonitrile, and $\mathrm{K}^{+}$can selectively be sensed in $\mathrm{MeOH}$. Currently we are exploring the synthesis of polymer bound analogs of the sensor to examine the detection of ions in aqueous fluids. We believe that since the synthesis of the sensor is modular, one can envision designing other sensors by using different receptor and/or sensor modules to attach to the $3 \alpha$ and $7 \alpha$ positions of chenodeoxycholic acid.

\section{Experimental Section}

General Procedures. All melting points were checked in Bךchi B-540 melting point apparatus. TLC was done on pre-coated silica gel plates (Merck) and stained with Liebermann Buchard reagent or observed under long/shortwave UV or in iodine vapor. Column chromatographic purifications were carried out on 100-200 mesh silica gel (Acme) using gravity columns. UVVis, IR and fluorescence spectra were recorded on Shimadzu UV2100, JASCO-70 FT-IR and Perkin-Elmer LS-50B spectrometers, respectively. NMR spectra were recorded on a $300 \mathrm{MHz}$ (JEOL Lambda-300) and $500 \mathrm{MHz}$ (BRUKER DRX 500) instruments in deuterated solvents as indicated; TMS or the residual solvent peaks were used as internal standards. Optical rotations were measured at $589 \mathrm{~nm}$ at $24^{\circ} \mathrm{C}$ on a JASCO DIP-370 digital polarimeter. Micro analyses were done on a Carlo Erba Strumentazione CHNS Analyser-model1106 and Flash EA 1112. MALDITOF-MS was done in KRATOS KOMPACT MALDI 4. LRMS and HRMS were recorded on Micromass Q-Tof micro.

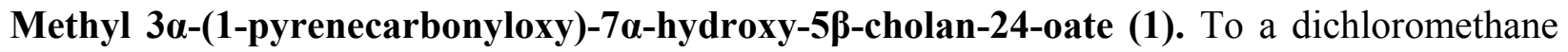
$(24 \mathrm{~mL})$ suspension of pyrene-1-COOH (1.16 g, $4.72 \mathrm{mmol})$, oxalyl chloride $(1 \mathrm{~mL}, 11.5 \mathrm{mmol})$ was added and stirred at room temperature for $45 \mathrm{~min}$. Excess oxalyl chloride was removed from the reaction mixture in vacuo. To a solution of methyl $3 \alpha, 7 \alpha$-dihydroxy-5 $\beta$-cholan-24-oate $(1.73 \mathrm{~g}$, $4.25 \mathrm{mmol})$ in dry dichloromethane $(15 \mathrm{~mL})$, triethylamine $(3 \mathrm{~mL})$, DMAP $(0.22 \mathrm{~g}, 1.8 \mathrm{mmol})$, and the freshly prepared solution of pyrene-1-carbonyl chloride in dichloromethane $(20 \mathrm{~mL})$ was added and the mixture was stirred at room temperature for $7 \mathrm{~h}$. Solvent was removed from the reaction mixture and the residue was dissolved in chloroform $(100 \mathrm{~mL})$ and washed with satd. $\mathrm{NaHCO}_{3}(100 \mathrm{~mL})$, water $(100 \mathrm{~mL})$ and finally with brine $(100 \mathrm{~mL})$. The clear organic layer was dried over anhyd. $\mathrm{Na}_{2} \mathrm{SO}_{4}$, and solvent was removed in vacuo. The crude product was chromatographed on a silica gel column $(100-200$ mesh, $3.1 \mathrm{~cm} \times 17 \mathrm{~cm})$ with $0-2 \%$ ethyl acetate $/ \mathrm{CHCl}_{3}$ to obtain $1.17 \mathrm{~g}(43 \%)$ of the pure product; mp $128-131{ }^{\circ} \mathrm{C} ;[\alpha]_{\mathrm{D}}{ }^{24} 31$ (c. 1.0 , $\left.\mathrm{CHCl}_{3}\right)$; IR $\left(\mathrm{KBr}, \mathrm{cm}^{-1}\right)$ 3558, 2937, 2867, 1737, 1689, 1251, 1231; ${ }^{1} \mathrm{H}-\mathrm{NMR}\left(300 \mathrm{MHz}, \mathrm{CDCl}_{3}\right)$ 
$\boldsymbol{\delta} 0.69(\mathrm{~s}, 3 \mathrm{H}) ; 0.94(\mathrm{~d}, J=6.0 \mathrm{~Hz}, 3 \mathrm{H}) ; 1.00(\mathrm{~s}, 3 \mathrm{H}) ; 1.17-2.62\left(\mathrm{~m}\right.$, steroidal $\mathrm{CH}$ and $\left.\mathrm{CH}_{2}\right)$; $3.67(\mathrm{~s}, 3 \mathrm{H}) ; 3.91(\mathrm{~s}, 1 \mathrm{H}) ; 5.05(\mathrm{~m}, 1 \mathrm{H}) ; 8.04-8.25(\mathrm{~m}, 7 \mathrm{H}$, aromatic H of pyrene); $8.63(\mathrm{~d}, J=$ $8.1 \mathrm{~Hz}) ; 9.26(\mathrm{~d}, J=9.1 \mathrm{~Hz}) .{ }^{13} \mathrm{C}-\mathrm{NMR}\left(75 \mathrm{MHz}, \mathrm{CDCl}_{3}\right) \boldsymbol{\delta} 11.66 ; 18.18 ; 20.54 ; 22.70 ; 23.59$; $26.99 ; 28.06 ; 30.89 ; 30.96 ; 32.80 ; 34.46 ; 35.09 ; 35.12 ; 35.28 ; 35.48 ; 39.30 ; 39.46 ; 41.35 ; 42.59$; $50.35 ; 51.44 ; 55.66 ; 68.38 ; 75.31 ; 124.00 ; 124.13 ; 124.33 ; 124.70 ; 124.90 ; 125.95 ; 126.04 ;$ $126.12 ; 127.09 ; 128.36 ; 129.16 ; 129.31 ; 130.30 ; 130.86 ; 130.91 ; 133.98 ; 167.62 ; 174.71$. HRMS: Calcd for $\left(\mathrm{M}^{+}+\mathrm{Na}\right)$ 657.35558; Found: 657.3556; Anal. Calcd for $\mathrm{C}_{42} \mathrm{H}_{50} \mathrm{O}_{5}$ : C 79.45; $\mathrm{H}$ 7.94. Found: C 79.40; H 7.91.

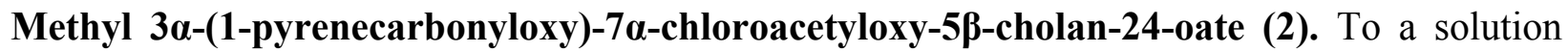
of $2(1.03 \mathrm{~g}, 1.62 \mathrm{mmol})$ in toluene $(15 \mathrm{~mL}), \mathrm{CaH}_{2}(0.20 \mathrm{~g}, 4.72 \mathrm{mmol}), \mathrm{nBu}_{4} \mathrm{~N}^{+} \mathrm{I}^{-}(0.17 \mathrm{~g}, 0.47$ $\mathrm{mmol})$ and chloroacetyl chloride $(700 \mu \mathrm{L}, 8.79 \mathrm{mmol})$ were added and the mixture was refluxed for $12 \mathrm{~h}$. The reaction mixture was filtered through celite and the residue was washed with ethyl acetate $(100 \mathrm{~mL})$. The filtrate was washed with satd. $\mathrm{NaHCO}_{3}$ solution $(100 \mathrm{~mL})$, water $(100$ $\mathrm{mL})$, brine $(100 \mathrm{~mL})$ and finally dried over anhyd. $\mathrm{Na}_{2} \mathrm{SO}_{4}$ and filtered. The solvent was removed in vacuo to yield the crude product $(1.23 \mathrm{~g})$, which was purified by column chromatography on silica gel (100-200 mesh, $30 \mathrm{~cm} \mathrm{x} 3 \mathrm{~cm}, 1.23 \mathrm{~g})$ using 4-10\% EtOAc/hexanes as the eluent. The pure product weighed $1 \mathrm{~g}(65 \%) ; \mathrm{mp} 163.1-166.4{ }^{\circ} \mathrm{C} ;[\alpha]_{\mathrm{D}}{ }^{24} 7$ (c. $\left.1.0, \mathrm{CHCl}_{3}\right)$; IR $\left(\mathrm{KBr}, \mathrm{cm}^{-1}\right) 3443,2942,2869,1735,1695,1255,1133 ;{ }^{1} \mathrm{H}-\mathrm{NMR}(300 \mathrm{MHz}$, $\left.\mathrm{CDCl}_{3}\right) \boldsymbol{\delta} 0.68(\mathrm{~s}, 3 \mathrm{H}) ; 0.93(\mathrm{~d}, J=6 \mathrm{~Hz}, 3 \mathrm{H}) ; 1.02(\mathrm{~s}, 3 \mathrm{H}) ; 1.12-2.4\left(\mathrm{~m}\right.$, steroidal $\mathrm{CH}$ and $\left.\mathrm{CH}_{2}\right)$; 3.66 (s, 3H); 4.03 (d, $J=15 \mathrm{~Hz}, 1 \mathrm{H}) ; 4.05$ (d, $J=15 \mathrm{~Hz}, 1 \mathrm{H}) ; 5.05$ (br. m, 2H); 8.04- 8.31 (m, aromatic protons of pyrene, $7 \mathrm{H}) ; 8.60(\mathrm{~d}, J=8.1 \mathrm{~Hz}, 1 \mathrm{H}) ; 9.210(\mathrm{~d}, J=9.3 \mathrm{~Hz}, 1 \mathrm{H}) .{ }^{13} \mathrm{C}-\mathrm{NMR}$ $\left(75 \mathrm{MHz}, \mathrm{CDCl}_{3}\right) \boldsymbol{\delta} 11.51 ; 18.13 ; 20.46 ; 22.49 ; 23.42 ; 26.89 ; 27.83 ; 30.76 ; 30.81 ; 31.19 ; 33.93$; $34.67 ; 34.79 ; 34.82 ; 35.10 ; 37.87 ; 39.20 ; 40.76 ; 41.17 ; 42.55 ; 50.07 ; 51.35 ; 55.52 ; 73.74 ; 74.78$; $123.95 ; 123.98 ; 124.16 ; 124.59 ; 124.69 ; 125.91 ; 126.04 ; 126.07 ; 126.96 ; 128.09 ; 129.10$; $129.28 ; 130.15 ; 130.69 ; 130.79 ; 133.93 ; 166.31 ; 167.44 ; 174.48$. LRMS Calcd for $\left(\mathrm{M}^{+}+\mathrm{Na}\right)$ 733.3; found: 733; Calcd for $\left(\mathrm{M}^{+}+\mathrm{K}\right)$ 749.3; Found: 749. Anal. Calcd for $\mathrm{C}_{44} \mathrm{H}_{51} \mathrm{ClO}_{6}$ : $\mathrm{C} 74.29$; H 7.23. Found: C 74.24; H 7.07.

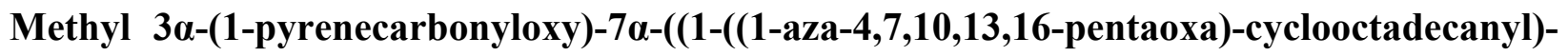

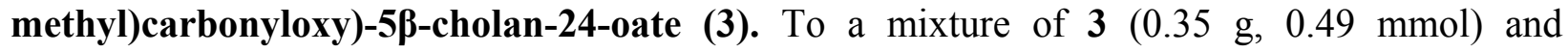
$\mathrm{Na}_{2} \mathrm{CO}_{3}(0.36 \mathrm{~g}, 3.42 \mathrm{mmol})$ in dry $\mathrm{CH}_{3} \mathrm{CN}, 1$-aza-18-crown-6 (0.21 g, $\left.0.8 \mathrm{mmol}\right)$ was added and the mixture was refluxed under nitrogen for $3 \mathrm{~d}$. The reaction mixture was filtered through celite, washed with EtOAc $(80 \mathrm{~mL})$ and the filtrate was washed with satd. $\mathrm{NaHCO}_{3}$ solution $(120 \mathrm{~mL})$, dried over anhyd. $\mathrm{Na}_{2} \mathrm{SO}_{4}$, filtered and solvent was removed in vacuo to get the crude product (0.50 g), which was purified by column chromatography on silica gel (100-200 mesh) using 1$10 \% \mathrm{MeOH} / \mathrm{CHCl}_{3}$ as the eluent followed by PTLC using $20 \% \mathrm{MeOH} / \mathrm{EtOAc}$ as the eluent to obtain $0.18 \mathrm{~g}(51 \%)$ pure product; $\mathrm{mp} 99.0-104.2{ }^{\circ} \mathrm{C}$; $[\alpha]_{\mathrm{D}}{ }^{24} 4.5$ (c. $\left.2.0, \mathrm{CHCl}_{3}\right)$; IR $\left(\mathrm{KBr}, \mathrm{cm}^{-1}\right)$ 3435, 2930, 2869, 1735, 1706; ${ }^{1} \mathrm{H}-\mathrm{NMR}\left(500 \mathrm{MHz}, \mathrm{CDCl}_{3}\right) \boldsymbol{\delta} 0.70$ (s, 3H); 0.96 (d, J=6.5 Hz, $3 \mathrm{H}) ; 1.04(\mathrm{~s}, 3 \mathrm{H}) ; 1.09-2.41\left(\mathrm{~m}\right.$, steroidal $\mathrm{CH}$ and $\left.\mathrm{CH}_{2}\right) ; 2.91(\mathrm{~s}, 3 \mathrm{H}) ; 3.31-3.54$ (m, aza-crown $\mathrm{CH}_{2}$ and acetyl $\left.\mathrm{CH}_{2}\right) ; 3.69(\mathrm{~s}, 3 \mathrm{H}) ; 4.98(\mathrm{~s}, 1 \mathrm{H}) ; 5.08(\mathrm{~m}, 1 \mathrm{H}) ; 8.08-8.30(\mathrm{~m}$, aromatic protons from pyrene, $7 \mathrm{H}) ; 8.62(\mathrm{~d}, J=8.5 \mathrm{~Hz}, 1 \mathrm{H}) ; 9.25(\mathrm{~d}, J=9.5 \mathrm{~Hz}, 1 \mathrm{H}) .{ }^{13} \mathrm{C}-\mathrm{NMR}\left(75 \mathrm{MHz}, \mathrm{CDCl}_{3}\right)$ 
ठ $11.46 ; 18.06 ; 20.45 ; 22.49 ; 23.36 ; 26.86 ; 27.77 ; 30.71 ; 31.24 ; 33.92 ; 34.64 ; 34.76 ; 34.89$; $35.04 ; 37.72 ; 39.18 ; 40.79 ; 42.42 ; 50.07 ; 51.24 ; 53.62 ; 55.50 ; 55.81 ; 69.66 ; 70.12 ; 74.78$; $123.91 ; 123.98 ; 124.51 ; 125.89 ; 126.00 ; 126.07 ; 126.88 ; 127.98 ; 129.11 ; 129.26 ; 130.07$; $130.64 ; 130.69 ; 133.85 ; 167.26 ; 171.03 ; 174.38$; HRMS Calcd for $\left(\mathrm{M}^{+}+\mathrm{H}\right)$ 938.5418; found: 938.5420; Anal. Calcd for $\mathrm{C}_{56} \mathrm{H}_{75} \mathrm{NO}_{11} .5 \mathrm{H}_{2} \mathrm{O}$ : C 65.41; H 8.33; N 1.36. Found C 65.23; H 7.87; N 1.42 .

\section{Acknowledgements}

This work was supported by a research grant from the Jawaharlal Nehru Centre for Advanced Scientific Research, Bangalore.

\section{References}

1. (a) de Silva, A. P.; Gunaratne, H. Q. N.; Gunnlaugsson,T.; Huxley,A. J. M.; McCoy,C. P.; Rademacher, J. T.; Rice,T. E. Chem. Rev 1997, 97, 1515. (b) Xu, X.; Xu, H.; Ji, H. Chem. Commun. 2001, 2092. (c) He, H.; Mortellaro, M.A.; Leiner, M.J.P.; Young, S.T.; Fraatz, R.J.; Tusa, J.K. Anal. Chem. 2003, 75, 549. (d) Benco, J.S.; Nienaber, H.A.; Dennen, K.; McGimpsey, W.G. J. Photochem. Photobiol. A Chem. 2002, 152, 33. (e) Benco, J.S.; Nienaber, H.A.; McGimpsey, W.G. Sens. Actuators, B 2002, 85 126. (f) Gunnlaugsson, T.; Nieuwenhuyzen, M.; Richard, L.; Thoss, V. Tetrahedron Lett. 2001, 42, 4725. (g) Ghosh, P.; Shukla, A.D.; Das, A. Tetrahedron Lett. 2002, 43, 7419. (h) Xiao, Y.; Qian, X. Tetrahedron Lett. 2003, 44, 2087. (i) Pearson, A.J.; Xiao, W. J. Org. Chem. 2003, 68, 5361. (j) Pearson, A.J.; Xiao, W. J. Org. Chem. 2003, 68, 5369. (k) Xia, W.S.; Schmehl, R.H.; Li, C.J. Eur. J. Org. Chem. 2000, 387. (1) de Silva, S.A.; Zavaleta, A.; Baron, D.E.; Allam, O.; Isidor, E.V.; Kashimura, N.; Percarpio, J.M. Tetrahedron Lett. 1997, 38, 2237. (m) Gunnlaugsson, T.; McCoy, C.P.; Morrow, R.J.; Phelan, C.; Stomeo, F. ARKIVOC 2003, (vii), 216.

2. Ji, H. F.; Dabestani, R.; Brown, G. M.; Hettich, R. L. Photochem. Photobiol. 1999, 69, 513.

3. Maitra. U.; D’Souza, L. J.; Vijay Kumar, P. Supramol. Chem. 1998, 10, 97.

4. Becker, V.; Streeck, C. Liebigs Ann. Chem. 1937, 531, 108.

5. (a) Timko, J.M.; Moore, S.S.; Walba,D.M.; Hiberty, P.C.; Cram, D.J., J. Am. Chem. Soc. 1977, 99, 4207. (b) Moore, S.S.; Tarnowski, T. L.; Newcomb, M.; Cram, D. J., J. Am. Chem. Soc. 1977, 99, 6398. (c) Kyba, E. P.; Helgeson, R. C.; Madan, K.; Gokel, G. W.; Moore, S.S.; Tarnowski, T. L.; Cram, D. J., J. Am. Chem. Soc. 1977, 99, 2564.

6. Gokel, G.W.; Hernandez, J.C.; Viscariello, A.M.; Arnold, K.A.; Campana, C.F.; Echegoyen, L.; Fronczek, F. R.; Gandour, R.D.; Morgan, C.R.; Trafton, J.E.; Miller, S.R.; Minganti, C.; Eiband, D.; Schultz, R.A.; Tamminen, M. J. Org. Chem. 1987, 52, 2963. 